\title{
Faktor-Faktor Yang Mempengaruhi Penawaran Dan Permintaan Bahan Pokok Di Indonesia
}

\author{
${ }^{1}$ Nilam Cahya, ${ }^{2}$ Kholida Atiyatul Maula \\ ${ }^{1-2}$ Fakultas Ekonomi dan Bisnis, Universitas Singaperbangsa Karawang
}

Article history

Received:04-Mei- 2021

Revised: 12-Juni-2021

Accepted:08-July-2021

*Corresponding Author:

Nilam Cahya,

Kholida Atiyatul Maula,

Fakultas Ekonomi dan

Bisnis,

Universitas

Singaperbangsa Karawang

Email:

@ gmail.com

\begin{abstract}
Abstrak: Bahan-bahan pokok di Indonesia merupakan aset negara yang perlu dimanfaatkan oleh masyarakat Indonesia dan pemerintahan Indonesia agar mendukung nilai ekspor dan impor bahan-bahan pokok menjadi lebih baik. Mengingat bahan-bahan pokok yang ada di Indonesia sangatlah melimpah dimana kondisi negara kita memiliki cuaca yang cukup baik untuk melakukan aktivitas pertanian yang banyak menghasilkan tanaman-tanaman berbahan pokok konsumsi di berbagai negara. Tujuan dari penulisan ini adalah untuk mengetahui faktor-fakto apa saja yang mempengaruhi adanya permintaan dan penawaran mengenai bahan-bahan pokok yang ada di Indonesia. Ada berbagai faktor yang mempengaruhi penawaran dan permintaan bahan pokok di Indonesia yang meliputi aktivitas ekspor dan impor, masalah struktural, lingkungan bisnis, dan juga hal-hal yang terjadi di lapangan pada permintaan dan penawaran yang ada di Indonesia pada bahan-bahan pokok yang kaya dan banyak di Indonesia.
\end{abstract}

Kata Kunci : Penawaran, Permintaan, Bahan pokok, Pertanian

\section{PENDAHULUAN}

Peran pertanian dalam perekonomian Indonesia tetap penting meskipun proses transformasi struktural tidak berjalan mulus seperti yang tertuang dalam buku teks pembangunan ekonomi. Pangsa pertanian dalam Produk Domestik Bruto (PDB) negara telah menurun menjadi 15,7 persen pada tahun 2011, tetapi pangsa tenaga kerja pertanian dalam total angkatan kerja pada tahun 2011 adalah 42,5 persen (Arifin, 2005). Lambatnya penurunan pangsa tenaga kerja merupakan indikasi belum tuntasnya transformasi struktural perekonomian Indonesia, termasuk lambatnya proses penyerapan di sektor industri dan jasa. Komoditas ekspor pertanian Indonesia memiliki potensi yang tinggi untuk mencapai daya saing yang lebih tinggi dan meningkatkan keberlanjutan di masa mendatang, meskipun terdapat beberapa permasalahan dan permasalahan masing-masing komoditas.

Upaya terbatas untuk menambah nilai produk pertanian dan lambatnya diversifikasi basis ekspor pertanian merupakan salah satu faktor penyebab ketidakseimbangan transformasi struktural tersebut. Basis ekspor primer yang kuat dan sistem produksi yang menguntungkan dari ekspor komoditas pertanian utama belum sepenuhnya dimanfaatkan, yang mungkin berisiko bagi masa depan perekonomian Indonesia pada umumnya. Ada juga masalah dengan keberlanjutan pembangunan ini, dari perspektif ekonomi serta sosial dan lingkungan, terutama karena perbedaan tingkat respons kebijakan dan sistem insentif untuk komoditas ekspor pertanian utama.

Kinerja komoditas pertanian utama dalam satu dekade terakhir cukup baik, menunjukkan tren peningkatan produksi, kecuali kopi dan karet alam pada tahun 2009. Penurunan produksi karet pada tahun 2009 disebabkan adanya "proses penyesuaian" di 
pasar dunia setelah mencatat rekor. harga minyak dan gas yang tinggi saat terjadi krisis ekonomi dunia pada tahun 2008. Permintaan karet sintetis kembali normal pada tahun 2009, sehingga harga karet anjlok secara signifikan ke rekor terendah US \$1,61 / kg (Kumar, 2011). Rendahnya tingkat harga karet ini, ditambah dengan tekanan untuk mengkonversi pohon karet menjadi kelapa sawit, memberikan kontribusi yang signifikan terhadap penurunan produksi karet pada tahun 2009.

Namun komoditas ekspor pertanian Indonesia masih menghadapi berbagai tantangan, yang sebagian besar bersifat sangat struktural, seperti sistem tanaman rakyat dengan hasil rendah, tekanan keberlanjutan, kualitas produksi yang rendah, investasi yang kurang, infrastruktur yang tidak memadai, praktik pertanian yang belum berkembang, dan pembatasan. peraturan Pemerintah. Masterplan Percepatan dan Pemekaran Perekonomian Indonesia (MP3EI) yang diusulkan oleh pemerintahan saat ini mencoba untuk mengatasi tantangan di atas. Jika rencana induk dilaksanakan sebagaimana mestinya, permintaan domestik untuk kopi, kakao, karet, kacang mete, dan mangga akan meningkat secara signifikan dalam waktu dekat. Peran permintaan domestik akan pangan dan produk pertanian yang terjangkau dari segmen pendapatan menengah ke bawah serta dari sektor manufaktur di dalam negeri dapat bersaing langsung dengan upaya mendorong ekspor produk pertanian tersebut. Dalam tatanan lingkungan ekonomi yang adil, daya saing produk-produk ini akan meningkat secara signifikan, sehingga masa depan pertanian Indonesia pada umumnya.

Dalam hal peningkatan daya saing dan keberlanjutan, faktor harga komoditas dunia hanyalah salah satu faktor yang berkontribusi terhadap kinerja produksi. Harga komoditas yang tinggi tidak cukup untuk mendorong petani kecil berinvestasi di pertanian, terutama di perkebunan yang periode pengembalian ekonominya lama. Investasi di bidang pertanian diperlukan untuk praktik pengelolaan, pengembangan lahan dan teknologi untuk menghasilkan hasil yang lebih baik dan mengisi kembali perkebunan tua. Persoalan semakin pelik karena mayoritas pelaku di pasar komoditas pertanian tersebut adalah petani kecil dengan ciri khas masing-masing. Petani kecil terkadang lebih peduli dengan harga di tingkat petani dan keuntungan ekonomi langsung, daripada fokus jangka panjang untuk meningkatkan investasi untuk produksi yang lebih baik di masa depan. Misalnya, pajak ekspor untuk meningkatkan nilai tambah di negara yang dikenakan pada komoditas tertentu seperti kakao (dan minyak sawit) mungkin tidak dipandang menguntungkan bagi petani, karena pajak ekspor biasanya menurunkan harga di tingkat petani yang diterima langsung oleh petani. Intervensi ini dapat menurunkan penerapan input tanaman, mengganggu pertumbuhan produksi di masa depan untuk komoditas tersebut secara luas.

Selain itu, isu keberlanjutan yang diberlakukan oleh negara maju terhadap komoditas ekspor pertanian Indonesia dapat mengancam daya saing tanaman tertentu. Misalnya, pengembangan kelapa sawit dituding sebagai salah satu penyumbang utama gas rumah kaca dan emisi karbon dunia. Perluasan areal panen kelapa sawit dikatakan terjadi dengan mengorbankan kawasan konservasi hutan alam dan lahan gambut, khususnya di Sumatera dan Kalimantan. Selain itu, biji kopi di Lampung juga dituding berkontribusi terhadap deforestasi, kerusakan keanekaragaman hayati, dan hilangnya habitat harimau dan gajah Sumatera karena beberapa praktik budidaya kopi terjadi di dalam kawasan Hutan Nasional dan konservasi Sumatera. Dalam hal ini, pembeli kopi aktif di negara maju 
didorong untuk tidak membeli dan menerima kopi Robusta dari Lampung atau dari tempat lain yang keterlacakannya buruk, tidak ada surat keterangan asal, dan sumber biji kopi yang tidak jelas.

Perspektif keberlanjutan telah mengubah struktur dan kinerja rantai pasokan komoditas ekspor pertanian utama di Indonesia. Oleh karena itu, studi yang mengidentifikasi dan menilai daya saing dan keberlanjutan komoditas utama ekspor pertanian menjadi sangat penting karena pasar dunia dan kepentingan domestik dari komoditas tersebut telah berubah cukup cepat dan lebih intensif dalam dekade terakhir. Kajian tersebut akan mengarah pada perubahan kebijakan dan strategi aksi untuk meningkatkan daya saing dan keberlanjutan komoditas ekspor pertanian penting di Indonesia.

Pertanian di Indonesia memiliki daya saing yang sangat berpengaruh untuk kepentingan domestik yang juga sering berubah-ubah secara intensif yang mempengaruhi bahan-bahan pokok yang ada di Indonesia .Dengan begitu, bahan pokok yang ada di Indonesia memiliki banyak faktor yang mempengaruhi penawaran serta permintaannya. Faktor-faktor tersebut mengindikasikan adanya perubahan serta perbandingan dari segi permintaan dan penawaran yang dapat bersaing dengan baik di Indonesia maupun di luar negeri.

Komoditas ekspor pertanian Indonesia memiliki tahapan yang berbeda dalam hal daya saing dan keberlanjutan. Tingkat daya saing minyak sawit mentah (CPO) tertinggi di antara semua ekspor pertanian, yang merupakan konsekuensi logis dari kinerja produksi dan ekspor yang tumbuh pesat dan menduduki posisi pertama di dunia. Produksi CPO pada 2011 sekitar 24 juta ton, tumbuh 5,1 persen per tahun, jauh di atas Malaysia yang kurang dari 20 juta ton. Namun, kesenjangan produktivitas antara petani kecil dan perkebunan skala besar, konflik lahan di lapangan dan tuduhan penghasil emisi karbon serta penurunan hutan alam telah berkontribusi pada tantangan keberlanjutan industri CPO di Indonesia. Beberapa bisnis minyak sawit besar di Indonesia telah menjadi anggota, Roundtable Sustainable Palm Oil (RSPO), badan sertifikasi utama sistem perdagangan minyak sawit. Menariknya, Asosiasi Kelapa Sawit Indonesia (IPOA atau secara lokal dikenal sebagai GAPKI) telah menarik keanggotaannya di RSPO, tetapi menjadi ko-promotor dengan sistem sertifikasi baru dan wajib Indonesia Sustainable Palm Oil (ISPO) dengan Pemerintah Indonesia (Fitzpatrick \& Jaeger, 2007).

Komoditas ekspor pertanian lainnya tidak semaju kelapa sawit baik dari segi daya saing maupun prinsip keberlanjutan. Kopi menempati urutan kedua dalam hal pendapatan ekspor dari pertanian, tetapi konsumsi kopi yang meningkat dan gaya hidup yang berubah di antara masyarakat perkotaan akan membentuk berbagai tahapan daya saing dan keberlanjutan. Pembeli dan pelaku utama rantai pasokan kopi dunia secara agresif mempromosikan beberapa perilaku baru tata kelola lingkungan perusahaan di industri kopi. Kekhawatiran yang meningkat tentang standar keberlanjutan muncul dengan sangat cepat dalam dua dekade terakhir, mungkin karena dinamika sektor swasta dan perusahaan multinasional. Sistem sertifikasi dan pelabelan juga berkembang pesat di sektor pangan global karena standar lingkungan dan sosial dalam ekonomi kopi memiliki implikasi serius dan jangka panjang bagi keberlanjutan ekosistem alam di daerah tropis dan mata pencaharian produsen kopi yang sebagian besar merupakan petani kecil. . Skema verifikasi 
rantai pasokan yang saat ini beroperasi dalam perdagangan kopi Indonesia termasuk 'Organik', 'Perdagangan Adil', 'Aliansi Hutan Hujan', 'Utz Kapeh', dan 'Praktik CAFÉ Starbucks', yang semuanya berupaya untuk mengatasi masalah lingkungan (dan sosial) di lokasi. produksi melalui sinyal pasar yang dikirim oleh pembeli di sepanjang rantai pasokan. Kemitraan sertifikasi terbaru yang diperkenalkan ke sektor kopi Indonesia adalah 4C (Kode Umum untuk Komunitas Kopi), yang bertujuan untuk mendorong keberlanjutan dalam rantai kopi hijau 'arus utama' dan untuk meningkatkan jumlah kopi yang memenuhi kriteria keberlanjutan dasar ekonomi, lingkungan. , dan sosial. Namun demikian, kemitraan global di sektor kopi ini kadang-kadang dipandang sebagai persaingan antar pembeli kemitraan kopi di Utara untuk menjamin ketersediaan pasokan kopi yang berkelanjutan dari negara-negara produsen di Selatan (Jeff Neilson, 2008).

Sektor kakao Indonesia sedang dalam tahapan proses revitalisasi untuk mengembalikan peran utamanya dalam pendapatan ekspor bagi petani kakao skala kecil seperti pada akhir tahun 1990-an. Gerakan Nasional (Gernas) untuk meningkatkan produksi kakao yang dimulai di Sulawesi pada tahun 2009, dengan mengembangkan kultur jaringan untuk pembibitan kakao, peningkatan kapasitas petani, perbaikan praktek pertanian di lapangan, dan peningkatan kualitas biji kakao dapat memberikan jalan yang lebih baik untuk meningkatkan daya saing industri kakao di masa depan. Cepat atau lambat, kemitraan sertifikasi global kakao akan memperluas operasinya di Indonesia karena permintaan pasar kakao akan membutuhkan standar keberlanjutan yang lebih tinggi dan persyaratan lain dari tata kelola lingkungan global. Namun, ketika pemerintah Indonesia saat ini memberlakukan pajak ekspor kakao untuk mengembangkan industri pengolahan hilir di dalam negeri, hasil bersih untuk meningkatkan daya saing mungkin tidak sebaik niat awal, terutama karena terbatasnya upaya untuk memperbaiki struktur pemasaran dan domestik. rantai pasok pasar kakao.

\section{METODE PENELITIAN}

Dalam penulisan ini, penulis menggunakan metode kualitatif dengan pendekatan studi kasus yang terdapat pada sumber-sumber bacaan yang digunakan penulis menggunakan studi dokumentasi. Studi dokumentasi adalah salah satu metode pengumpulan data kualitatif dengan melihat atau menganalisis dokumen yang dibuat oleh subjek sendiri atau orang lain tentang subjek. Studi dokumentasi merupakan salah satu cara yang dapat dilakukan untuk mendapatkan gambaran dari sudut pandang subjek melalui suatu media tertulis atau dibuat langsung oleh subjek yang bersangkutan. Sumber yang digunakan pada studi dokumnetasi ini berupa jurnal-jurnal terkait dan sumber-sumber internet lainnya.

Populasi dalam penelitian laporan ini adalah perkembangan dari hasil teh yang dihasilkan oleh indonesia. Sampel penelitian diambil dari ruang lingkup dalam garis besar aja, karena jika kami mengambil sampel dari beberapa daerah di indonesia cukup rumit dikarenakan penghasilan teh di indonesia cukup banyak.

\section{HASIL DAN PEMBAHASAN \\ Hasil}

Masalah Struktural yang Mempengaruhi Penawaran dan Permintaan 
Indonesia merupakan pemain kecil ekonomi teh dunia, hanya menyumbang 4 persen dari produksi teh dunia, dan hanya memproduksi 150 ribu ton pada tahun 2010 . Indonesia menempati urutan ke 7 negara penghasil teh, jauh lebih rendah dari China (memproduksi sekitar 1,56 juta ton), India (978 ribu ton), Kenya (514 ribu ton), Sri Lanka (290 ribu ton), Vietnam (250 ribu ton), dan Turki (200 ribu ton). Peringkat ini merupakan penurunan dari peringkat kelima pada tahun 2005 yang sebagian besar disebabkan oleh penurunan produksi teh. Secara umum, penurunan produksi teh Indonesia sekitar 1 persen per tahun dalam sepuluh tahun terakhir lebih disebabkan oleh menurunnya luas panen sebesar 1,9 persen per tahun. Luas panen perkebunan teh menurun dari 153 ribu hektar pada tahun 2000 menjadi hanya 124 ribu hektar pada tahun 2010. Rendahnya harga di tingkat petani dan tingginya permintaan lahan pertanian dan penggunaan lainnya telah berkontribusi pada permasalahan struktural ekonomi teh dalam satu dekade terakhir (Rohayati Suprihatini, 2005).

Masalah struktural ini memberikan ancaman serius bagi 320 ribu pekerja yang terlibat di industri teh, dimana sekitar 1,3 juta orang yang menggantungkan hidupnya pada ekonomi teh berada dalam kondisi mata pencaharian yang kritis. Jika tidak ada tindakan kebijakan di tahun-tahun mendatang, kontribusi tahunan sebesar US \$ 110 juta dari pendapatan luar negeri teh akan hilang dalam waktu yang relatif singkat. Demikian pula, kontribusi ekonomi teh sebesar Rp 1,2 triliun terhadap Produk Domestik Bruto (PDB) Indonesia akan sirna, kecuali jika ada strategi serius dan sistematis untuk merevitalisasi ekonomi teh, dari bisnis hulu hingga hilir. Dengan produktivitas yang relatif konstan, peningkatan biaya produksi teh, pendapatan ekonomi dari pembudidayaan dan pengolahan teh tampaknya tidak berpotensi tinggi untuk mendorong pembangunan ekonomi lokal, apalagi berkontribusi pada pengentasan kemiskinan di pedesaan (Jeffrey Neilson \& Pritchard, 2007).

Perkembangan industri hilir dan sektor pengolahan teh di Indonesia cukup lambat antara lain karena insentif investasi yang buruk, pajak pertambahan nilai sebesar 10 persen untuk setiap kegiatan pengolahan, kurangnya dukungan pemerintah yang konsisten. PPN $10 \%$ menghambat perkembangan yang tepat di sektor hilir, yang mengakibatkan produsen lebih memilih mengekspor teh curah daripada teh olahan / kemasan. Meski PPN 10 persen telah dicabut pada Januari 2007, namun efek distorsi tetap ada, karena KPP Provinsi belum mengeluarkan pedoman pelaksanaan kebijakan tersebut. Krisis ekonomi global yang terjadi sejak tahun 2008 turut berkontribusi pada menurunnya kinerja ekspor teh Indonesia. Ratarata harga teh dunia turun dari US \$2,92 per kilogram pada tahun 2011 menjadi US \$2,69 per kilogram pada tahun 2012, meskipun harga tersebut menunjukkan tren peningkatan sejak Maret 2012. Faktor yang mempengaruhi kinerja ekspor teh Indonesia antara lain adanya permintaan dan penawaran yang ada. teh di pasar global, kualitas produk teh, hambatan perdagangan di negara tujuan ((Rohayati Suprihatini, 2005); (Kustanti \& Widiyanti, 2007)).

\section{Lingkungan Bisnis Yang Mempengaruhipermintaan Dan Penawaran}

Pertama, biaya bisnis tinggi. Ada kebutuhan mendesak untuk penyederhanaan peraturan karena biaya tambahan yang dibebankan oleh rezim peraturan Indonesia pada bisnis. Negara ini terus berada di peringkat yang buruk dalam hal kemudahan berbisnis, 
dengan sedikit peningkatan yang terlihat sejak tahun 2005. Dalam peringkat Kemudahan Berbisnis tahun 2015 dari Bank Dunia, Indonesia berada di peringkat 114 dari 189 negara, jauh di belakang Malaysia, Thailand, Vietnam, dan Filipina. Peringkat Indonesia untuk memulai bisnis, menangani izin konstruksi, membayar pajak, dan menegakkan kontrak sangat rendah, dan lebih setara dengan negara berkembang berpenghasilan rendah daripada negara berpenghasilan menengah. Menurut laporan Doing Business terbaru, hambatan utama untuk memulai dan menjalankan bisnis di Indonesia terkait dengan koordinasi yang buruk di dalam dan di antara lembaga pemerintah, regulasi yang berlebihan oleh berbagai lembaga, dan izin usaha yang diwajibkan oleh berbagai lapisan pemerintah. Selain itu, kesulitan dalam penegakan kontrak karena lemahnya supremasi hukum. Bahkan proyek konstruksi sederhana dapat membuat frustrasi - misalnya, 17 prosedur dan izin berbeda diperlukan sebelum konstruksi dapat dilakukan, membutuhkan lebih dari 200 hari untuk menyelesaikannya, yang mana lebih dari 50\% lebih tinggi daripada di bagian lain Asia Timur dan Pasifik.

Kedua, korupsi. Indonesia telah mengubah dirinya sejak tahun 1998 menjadi negara yang relatif terbuka, stabil, dan demokratis. Bersamaan dengan itu, upaya pemberantasan korupsi dan perbaikan tata kelola telah dilakukan. Kebebasan pers telah ditingkatkan; kewenangan dilimpahkan ke daerah; check and balances antara eksekutif, legislatif, dan yudikatif diperkuat; peran formal pasukan keamanan dalam proses politik diakhiri; dan kerangka kelembagaan, termasuk pembentukan Komisi Pemberantasan Korupsi, dikembangkan. Namun, undang-undang yang sudah ketinggalan zaman dan beban berat dari instruksi yang berorientasi pada administrasi, dikombinasikan dengan pemerintahan yang dibayar rendah dan semakin terfragmentasi dan layanan sipil, telah meningkatkan ruang lingkup kebijaksanaan birokrasi dan korupsi. Dengan desentralisasi, jumlah individu yang mencari suap dan suap dilaporkan meningkat, dan biaya korupsi menjadi kurang dapat diprediksi. Sekitar 8 dari 10 orang Indonesia mengatakan bahwa korupsi tersebar luas di pemerintahan dan bisnis, yang persentasenya lebih tinggi daripada di bagian lain Asia Tenggara.

Ketiga, sektor keuangan yang dangkal. Akses ke kredit merupakan kendala yang signifikan bagi kegiatan sektor swasta di Indonesia, terutama untuk usaha mikro dan kecil. Sektor keuangan didominasi oleh bank ( $78 \%$ aset) dan klaimnya kepada sektor swasta hanya 35\%, dibandingkan dengan sekitar 100\% untuk Malaysia, Thailand, dan Filipina. Pada akhir 2015, kapitalisasi pasar saham hanya 50\% dari PDB (dibandingkan dengan $160 \%$ di Malaysia, 2012), dan sekuritas hutang yang beredar setara dengan 15\% dari PDB (dibandingkan dengan $120 \%$ di Malaysia, 2012). Baik pasar uang maupun pasar valuta asing tipis, dengan penggunaan swap dan opsi terbatas. Pasar keuangan yang lebih dalam dibutuhkan untuk memobilisasi tabungan guna mendanai investasi dan untuk memenuhi kebutuhan transaksi bisnis. Meskipun sektor perbankan sehat dan diatur dengan baik, diperlukan upaya yang substansial untuk mengembangkan pasar uang, pasar valuta asing, dan pasar modal. Munculnya e-banking, e-money, dan peer-to-peer banking seharusnya meningkatkan inklusi keuangan, tetapi menimbulkan tantangan regulasi dan pengawasan baru (R Suprihatini, 2011).

\section{Pembahasan}


Indonesia adalah pemain kecil ekonomi bahan pokok dunia, hanya menyumbang 8 persen dari ekspor dunia lebih dari 1,6 juta ton per tahun. Produksi bahan pokok telah tumbuh dengan stabil dalam dekade terakhir, mengharapkan peran yang meningkat di pasar dunia dalam waktu dekat. Pada tahun 2010 produksi bahan pokok di Indonesia lebih dari 145 ribu ton per tahun, sedikit meningkat setelah mengalami penurunan yang cukup signifikan pada tahun 2009 akibat kondisi basah yang cukup lama. Lebih dari 70 persen produksi bahan pokok diekspor ke pasar dunia, menghasilkan sekitar US \$ 82 juta. Volume dan nilai ekspor yang terus meningkat dalam satu dekade terakhir, salah satu tanda meningkatnya daya saing industri bahan pokok (R Suprihatini, 2011).

Bahan-bahan pokok di Indoneisa awalnya dikembangkan sebagai pohon konservasi pada tahun 1980-an, ketika Indonesia mengalami laju deforestasi yang tinggi yang menyebabkan bertambahnya luas lahan kritis, terutama di kawasan timur Indonesia. Produksi bahan-bahan pokok di provinsi Jawa Timur, Jawa Tengah dan provinsi lain juga berasal dari daerah kering, seperti di Pulau Madura di Jawa Timur, pesisir utara Jawa Tengah, Bali utara, dll. Banyak bahan-bahan pokok juga tumbuh penting di provinsi Nusa Tenggara Barat, terutama di pulau Sumbawa, bagian provinsi yang kering. Sejak pertengahan tahun 1990-an, pemerintah dan swasta telah berupaya untuk memberikan nilai tambah pada produksi bahan pokok dengan menyediakan alat sederhana. Upaya ini tidak hanya berkontribusi pada nilai tambah komoditas tetapi juga memberikan kesempatan kerja bagi perempuan pedesaan di unit penembakan atau sentra pengolahan, dan / atau koperasi pedesaan yang menangani usaha bahan-bahan pokok. Sektor swasta dalam usaha bahan pokok memiliki keuntungan dalam mengamankan pasokan kacang untuk usaha pengolahannya sendiri untuk memenuhi pasar dalam negeri dan sebagian lagi untuk pasar ekspor (Wibawa et al., 2002).

Sayangnya, yang dilakukan oleh swasta dalam usaha bahan-bahan pokok di sentra produksi bahan makanan masih sangat terbatas. Mayoritas produksi bahan pokok ke pasar dunia tanpa mengupas. Kecenderungan ini juga terjadi di negara-negara produsen bahan pokok lainnya, di mana sekitar 40 persen tanaman bahan-bahan pokok dunia dikupas di luar negara asalnya. Nilai tambah ekonomi bahan pokok sebagian besar ditangkap oleh India dan Vietnam, dua negara yang mengimpor bahan pokok dalam jumlah besar dari negara-negara Asia dan Afrika serta melakukan kegiatan pengupasan dan pengolahan lainnya di negaranya. Namun apabila pelaku usaha memandang bahwa penambalan bahan pokok merupakan kegiatan usaha yang menguntungkan, maka industri bahan pokok di Indonesia lambat laun akan berkembang lebih baik, sehingga daya saing industri tersebut akan meningkat secara signifikan. Perkembangan produk turunan bahan pokok juga berkembang sangat pesat di Indonesia, seiring perkembangan industri makanan yang menggunakan berbagai bahan pokok sebagai inputnya cukup menjanjikan dalam beberapa tahun terakhir.

Bahan-bahan pokok Indonesia diterima dengan baik secara internasional dalam pasar kompetitif dari berbagai negara (Fitzpatrick \& Jaeger, 2007). Ada beberapa keunggulan komparatif: pertama, kernel yield (berat biji / berat biji dalam cangkang) baik; kedua, Indonesia memiliki posisi geografis yang baik untuk melayani dua pembeli utama kacang dalam cangkang, India dan Vietnam; dan ketiga, waktu panen ideal karena tidak ada produsen pesaing lain yang mampu memasok pembeli pada periode kuartal keempat 
ketika Indonesia biasanya memanen.

\section{KESIMPULAN}

Indonesia memiliki potensi untuk mencapai tingkat pertumbuhan ekonomi lingkungan pertanian yang lebih tinggi. Populasi konsumen berpenghasilan menengah yang besar dan terus berkembang, bonus demografis, tingkat pencapaian pendidikan yang lebih tinggi, perpindahan tenaga kerja yang stabil dari pertanian dengan produktivitas rendah ke sektor lain, dan pengejaran teknologi seharusnya secara substansial meningkatkan potensi pertumbuhan negara. Integrasi ASEAN akan menambah tekanan persaingan, tetapi juga akan membantu mengintegrasikan Indonesia ke dalam salah satu kawasan yang tumbuh paling pesat di dunia. Peluang investasi dan pertumbuhan baru juga diciptakan saat RRT menyeimbangkan kembali dan bagian dari manufaktur padat karya bergeser ke pusat produksi lain.

Indonesia telah beroperasi jauh di bawah potensi pertumbuhannya selama bertahuntahun karena berbagai kendala. Manajemen makroekonomi telah dilakukan dengan hatihati, tetapi belum cukup untuk menahan penurunan daya saing makro. Ketergantungan yang besar pada ekspor komoditas, selama tahun-tahun ledakan komoditas, telah berkontribusi pada apresiasi nilai tukar yang nyata, sehingga mengurangi daya saing sektor non-komoditas yang dapat diperdagangkan. Hal ini juga membuat Indonesia rentan terhadap volatilitas pendapatan ekspor dan arus modal. Setelah krisis keuangan Asia, pemerintah memprioritaskan stabilitas fiskal dan moneter daripada kebijakan ekspansif, dan telah mengurangi tingkat utang publik secara drastis. Konsolidasi fiskal, selain membantu membangun penyangga terhadap guncangan, juga telah mengurangi kontribusi kebijakan fiskal terhadap pertumbuhan.

\section{DAFTAR PUSTAKA}

Arifin, B. (2005). Supply-chain of natural rubber in Indonesia. Jurnal Manajemen \& Agribisnis, 2(1), 1-16.

Fitzpatrick, J., \& Jaeger, P. (2007). Indonesia Cashew Sector Development Study Corporation. Research Report for the International Finance Makassar: IFC.

Kumar, P. (2011). Indonesia Food \& Agribusiness Outlook, Leading the Southeast Asian Growth Story. Utrecht: Rabobank International Food \& Agribusiness Research and Advisory.

Kustanti, V. R., \& Widiyanti, T. (2007). Research on supply chain in the tea sector in Indonesia. Jakarta: The Business Watch Indonesia.

Neilson, Jeff. (2008). Global private regulation and value-chain restructuring in Indonesian smallholder coffee systems. World Development, 36(9), 1607-1622.

Neilson, Jeffrey, \& Pritchard, B. (2007). Green coffee? The contradictions of global sustainability initiatives from an Indian perspective. Development Policy Review, 25(3), 311-331.

Suprihatini, R. (2011). Kebijakan yang Perlu Diperjuangkan untuk Revitalisasi Agribisnis 
Teh Nasional(Proposed Policies for Revitalizing the National Tea Agribusiness). Gambung, West Java: The Research Institute for Tea and Cinchona (RITC).

Suprihatini, Rohayati. (2005). Indonesian tea export competitiveness in the world's tea market. Jurnal Agro Ekonomi, 23(1), 1-29.

Wibawa, G., Rosyid, M. ., Nancy, C., Noordwijk, M. va., \& Joshi, L. (2002). Marketing Rubber in Jambi, Indonesia: Traditional Systems and the New Indonesian National Standard (SNI). Working Paper of the Indonesian Rubber Research Institute (IRRI) at Sembawa, Palembang and World Agroforestry Center (ICRAF) Southeast Asia, Bogor. 